\title{
PENGARUH LAMA PENYIMPANAN TERHADAP KADAR VITAMIN C BUAH APEL (Malus sylvestris Mill.)
}

\author{
Latief Abdul Maajid, Sunarmi, Ag. Kirwanto \\ Kementerian Kesehatan Politeknik Kesehatan Surakarta Jurusan Jamu \\ Diterima : 15 Agustus 2018, Disetujui : 27 Agustus 2018
}

\begin{abstract}
Background: Vitamin $C$ is easily soluble in water, and is the most labile vitamin because it is easily damaged by heat and storage. Vitamin $C$ is contained in various fresh vegetables and fruits. One fruit that contains vitamin $C$ is apple. The purpose of this study was to determine the effect of storage time on apple vitamin $C$ levels. 12 apples were grouped into 4 groups at 0, 2, 4, and 6 days at room temperature. Vitamin $C$ levels of apples were analyzed using a UV-Vis spectrophotometer at a wavelength of $290 \mathrm{~nm}$. The highest vitamin C level was found in the 0 day storage period, which was equal to $0.335 \%$ and the lowest vitamin C level was found at 6 days of storage, which was $0.118 \%$. Vitamin C levels of apples decrease with increasing storage time. Method: The data obtained were analyzed by one-way ANOVA test. Result:The results showed that storage time had a significant effect $(p<0.05)$ on decreasing levels of apple vitamin C. Conclusion: Based on the results of these studies it can be concluded that the level of vitamin $C$ in apples decreases along with the length of storage at room temperature. Therefore it is recommended that people consume fresh apples and not store apples at room temperature to get enough vitamin $C$.
\end{abstract}

Keywords: Apple, vitamin C, storage time

\section{PENDAHULUAN}

Vitamin C merupakan vitamin yang mudah larut dalam air, vitamin yang paling labil karena mudah rusak oleh panas dan udara (Sulistyoningsih, 2011:38). Vitamin C, juga dikenal sebagai asam L-askorbat, adalah vitamin yang larut dalam air yang secara alami terdapat pada beberapa makanan, ditambahkan ke makanan lain, dan tersedia sebagai suplemen makanan. Manusia, tidak seperti kebanyakan hewan, tidak dapat mensintesis vitamin C secara endogen, jadi ini adalah komponen makanan yang penting.Vitamin $\mathrm{C}$ diperlukan untuk biosintesa kolagen, L-karnitin, dan neurotransmitter tertentu; Vitamin $\mathrm{C}$ juga terlibat dalam metabolisme protein.
Kolagen adalah komponen penting jaringan ikat, yang memainkan peran penting dalam penyembuhan luka. Vitamin $\mathrm{C}$ juga merupakan antioksidan fisiologis pentingdan telah terbukti dapat menumbuhkan antioksidan lain di dalam tubuh. vitamin $\mathrm{C}$ memainkan peran penting dalam fungsi kekebalan tubuh dan meningkatkan penyerapan zat besi nonhem], bentuk zat besi hadir dalam makanan nabati. Kurangnya asupan vitamin $\mathrm{C}$ menyebabkan kudis, yang ditandai dengan kelelahan atau kelesuan, kelemahan jaringan ikat yang meluas, dan kerapuhan kapiler (anonim, 2018). Tanda kekurangan vitamin $\mathrm{C}$ dalam kudis termasuk kulit perubahan, kerapuhan kapiler darah, pembusukan gusi, 
gigikehilangan, dan patah tulang, banyak di antaranya dapat dikaitkanuntuk sintesis kolagen yang kurang (Murray et al, 2003).

Vitamin ini merupakan fresh food vitamin karena sumber utamanya adalah buah-buahan dan sayuran segar (Linder, 1992 dalam Safaryani et.al., 2007). Salah satu buah yang mengandung vitamin C adalah apel (Fauziah, 2015). Apel (Malus sylvestris Mill.) termasuk dalam family Rosaceae, merupakan jenis buah yang iasanya berwarna merah, tapi ada juga apel yang berwarna hijau dan kuning. Kulitnya agaklembek, daging buahnya keras dan memiliki biji di dalamnya. Buah apelmemiliki kandungan vitamin C sebanyak $2 \mathrm{mg} / 100 \mathrm{~g}$. Selain vitamin $\mathrm{C}$, buahapel juga mengandung senyawa fenol seperti quercetin dan epicatechinyang berfungsi sebagai antioksidan dan dapat mengurangi resiko terkenakanker. Sebuah studi membuktikan bahwa tikus yang diberi ekstrak apellebih rendah terkena resiko kanker usus sebesar 43\% (Fauziah, 2015).

Vitamin $\mathrm{C}$ adalah vitamin yang paling tidak stabil dari semuavitamin dan mudah rusak elama pemrosesan dan penyimpanan. Laju perusakan meningkat karena kerja logam, terutama Tembaga dan besi,dan juga oleh kerja enzim. Enzim yang mengandung tembaga atau besidalam gugus prostetiknya merupakan katalis yang efisien untukpenguraian asam askorbat (deMan, 1997:411).

Kandungan vitamin pada buah dan sayuran akan berubah pada berbagai kondisi dan lama waktu penyimpanan. Helmiyesi et al. (2008) dalam penelitiannya yang berjudul "PengaruhLama Penyimpanan Terhadap Kadar Gula dan Vitamin C pada Buah JerukSiam (Citrus nobilis Var: microcarpa)" mendapatkan kesimpulan bahwakadar vitamin $\mathrm{C}$ pada buah jeruk siam mengalami penurunan padapenyimpanan 10 dan 15 hari. Hal serupa mungkin juga terjadi pada buahapel yang melalui proses penyimpanan. Karena mengandung vitamin $\mathrm{C}$,apel akan mudah rusak jika disimpan di udara bebas karena vitamin Crentan terhadap panas dan udara.

Tujuan dari penelitian ini adalah untuk mengetahui pengaruh penyimpanan terhadap kadar vitamin $\mathrm{C}$ buah apel.

\section{METODE PENELITIAN}

Penelitian ini merupakan quasi eksperimen dengan rancangan one-shoot case study. Variabel terikat adalahh lamanya waktu penyimpanan dan variabel terikat berupa kadar vitamin $\mathrm{C}$ buah apel. Buah apel diperoleh dari swalayan di Surakarta sebanyak 12 buah dikelompokkan secara acak menjadi 4 kelompok yang masing-masing kelompok terdiri dari 3 buah apel. Masing-masing apel yang sudah dikelompokkan kemudian disimpan pada lama penyimpanan $0,2,4$, dan 6 hari pada suhu kamar $\left(25^{\circ} \mathrm{C}-30^{\circ} \mathrm{C}\right)$. Hari ke 0 dihitung pada saat hari pembelian. Buah apel dicuci, dikupas dan dibuang bijinya. Setelah itu apel dimasukkan ke dalam juicer untuk diambil sarinya. Asam askorbat dibuat seri konsentrasi 10, 20, 30, 40, dan 50 ppm dan diukur absorbansinya pada panjang gelombang $290 \mathrm{~nm}$ menggunakan spektrofotometri UV-vis. Hubungan absorbansi dan konsentrasi dibuat kurva standar. Ekstrak buah apel konsentrasi 10.000 ppm diukur absorbansi pada panjang gelombang $290 \mathrm{~nm}$. Nilai absorbansiyang diperoleh dimasukkan ke persamaan kurva baku sehingga nilai $\mathrm{x}$ atau konsentrasi vitamin $\mathrm{C}$ dalam sampel dapat dihitung (Karinda, 2013). Langkah 
terakhir adalah menghitung kadar vitamin C pada ekstrak sampel dengan rumus :

$$
\% \text { vitamin } \frac{\text { Konsentrasi Vitamin C }}{\text { Konsentrasi sampel }} \times 100
$$

Data kadar vitamin $\mathrm{C}$ diuji normalitas dengan kolmogorov smirnov dan dilanjutkan dengan one way ANOVA dengan tingkat kepercayaan $95 \%$.

\section{HASIL PENELITIAN}

Hasil analisis kadar vitamin $\mathrm{C}$ buah apel disajikan dalam bentuk tabel sebagai berikut :

Tabel 1. Prosentase Kadar Vitamin C Buah Apel

\begin{tabular}{cccc}
\hline $\begin{array}{c}\text { Lama } \\
\text { Penyimpanan }\end{array}$ & $\begin{array}{c}\text { Buah } \\
\text { Apel }\end{array}$ & $\begin{array}{c}\text { Kadar } \\
\text { Vitamin C }\end{array}$ & $\begin{array}{c}\text { Rata- } \\
\text { rata }\end{array}$ \\
\hline \multirow{2}{*}{0} & 1 & 0,306 & \\
& 2 & 0,305 & 0,335 \\
& 3 & 0,395 & \\
2 & 1 & 0,290 & \\
& 2 & 0,195 & 0,268 \\
& 3 & 0,318 & \\
4 & 1 & 0,101 & \\
& 2 & 0,138 & 0,119 \\
& 3 & 0,119 & \\
6 & 1 & 0,063 & \\
& 2 & 0,174 & 0,118 \\
& 3 & 0,116 & \\
\hline
\end{tabular}

Berdasarkan tabel 1. menunjukkan bahwa kelompok apel yang belum diberi perlakuan mempunyai rata-rata kadar vitamin C sebesar 0,335\%. Sedangkan pada kelompok perlakuan (lama penyimpanan 2, 4, dan 6 hari) menunjukkan rata-rata kadar vitamin $\mathrm{C}$ tertinggi pada lama penyimpanan 2 hari dan rata-rata kadar vitamin $\mathrm{C}$ terendah pada lama penyimpanan 6 hari. Rata-rata kadar vitamin $\mathrm{C}$ semakin menurun seiring dengan bertambahnya lama Penyimpanan. Hasil uji normalitas Kolmogorof Smirnov pada penelitian ini menunjukan $\mathrm{p}$ value $>0,05$ yang berarti data berdistribusi normal. Hasil uji homogenitas menunjukkan $\mathrm{p}$ value $>0,05$ yang berarti semua varian populasi adalah sama (homogen). Hasil uji One Way Anova didapatkan nilai $\mathrm{p}<0,05$ yang berarti bahwa terdapat pengaruh yang bermakna lama penyimpanan terhadap penurunan kadar vitamin $\mathrm{C}$ buah apel.

Penelitian ini menggunakan bahan buah apel yang banyak mengandung vitamin. Salah satu vitamin yang terkandung dalam buah apel adalah vitamin C. Hasil dari penelitian ini menunjukkan prosentase kadar vitamin $\mathrm{C}$ buah apel pada kelompok perlakuan lama penyimpanan 2, 4, dan 6 hari, dengan prosentase rata-rata kadar vitamin $\mathrm{C}$ tertinggi terdapat pada lama penyimpanan 2 hari yaitu sebesar $0,268 \%$ dan prosentase rata-rata kadar vitamin $\mathrm{C}$ terendah pada lama penyimpanan 6 hari yaitu sebesar $0,118 \%$. Kadar vitamin C buah apel pada masing-masing kelompok perlakuan $(2,4$, dan 6 hari) menunjukkan kadar vitamin $\mathrm{C}$ yang semakin menurun seiring bertambahnya lama penyimpanan. Hal ini sesuai dengan hasil penelitian Helmiyesi et. al. (2008) menunjukkan bahwa kadar vitamin $\mathrm{C}$ menurun seiring bertambahnya lama penyimpanan. Menurut deMan (1997) vitamin C adalah vitamin yang paling tidak stabil dari semua vitamin yang ada, karena mudah rusak selama pemrosesan dan penyimpanan. Menurut Sulistyoningsih (2011) vitamin C merupakan vitamin yang paling labil karena mudah rusak oleh panas dan udara.

\section{PEMBAHASAN}

Hasil uji One Way Anova didapatkan nilai probabilitasnya $<\alpha$ (tingkat signifikansi) yaitu $0,02<0,05$ 
yang menunjukkan bahwa nilai probabilitas lebih kecil dari nilai signifikansi, sehingga dapat disimpulkan bahwa terdapat perbedaan pengaruh yang bermakna dari nilai rata-rata kadar vitamin $\mathrm{C}$ setiap kelompok perlakuan. Hal ini membuktikan bahwa kandungan vitamin $\mathrm{C}$ buah apel dipengaruhi oleh lama penyimpanan. Kesimpulan ini tidak sesuai dengan penelitian yang dilakukan oleh Rachmawati dkk. (2009) mengenai Pengaruh Suhu Dan Lama Penyimpanan Terhadap Kandungan Vitamin C Pada Cabai Rawit Putih (Capsicum frustescens) bahwa lama penyimpanan berpengaruh tidak nyata terhadap kandungan vitamin $\mathrm{C}$ pada cabai rawit putih.

Penurunan kadar vitamin C secara nyata pada penelitian ini dikarenakan vitamin $\mathrm{C}$ mudah sekali terdegradasi, baik oleh temperatur, cahaya maupun udara sekitar sehingga kadar vitamin C berkurang. Proses kerusakan atau penurunan vitamin $\mathrm{C}$ ini disebut oksidasi. Secara umum reaksi oksidasi vitamin C ada dua macam yaitu oksidasi spontan dan tidak spontan. Proses oksidasi spontan adalah proses oksidasi yang terjadi tanpa menggunakan enzim. Sedangkan proses oksidasi tidak spontan yaitu reaksi yang terjadi dengan penambahan enzim (Andarwulan dan Sutrisno, 1992 dalam Helmiyesi dkk., 2008).

Pada penelitian ini reaksi yang terjadi adalah proses oksidasi spontan yaitu dengan adanya pengaruh dari udara sekitar. Mekanisme oksidasi spontan terjadi sebagai berikut : monoanion asam askorbat bereaksi dengan molekul oksigen menghasilkan radikal anion askorbat dan $\mathrm{H} 2 \mathrm{O}$ yang diikuti pembentukan dehidro asam askorbat dan hydrogen peroksida. Dehidro asam askorbat (asam Ldehidroaskorbat) merupakan bentuk oksidasi dari asam L-askorbat yang masih mempunyai keaktifan sebagai vitamin $C$. Namun asam L-dehidroaskorbat bersifat sangat labil dan dapat mengalami perubahan menjadi 2.3-L-diketogulonat (DKG).DKG yang terbentuk sudah tidak mempunyai keaktifan vitamin $\mathrm{C}$ lagi sehingga jika DKG tersebut sudah terbentuk maka akan mengurangi bahkan menghilangkan vitamin $\mathrm{C}$ yang ada dalam produk (Adarwulan dan Sutrisno, 1992 dalam Helmiyesi dkk., 2008).

\section{KESIMPULAN DAN SARAN}

Berdasarkan hasil penelitian tersebut dapat disimpulkan bahwa kadar vitamin $\mathrm{C}$ pada buah apel semakin turun seiring dengan lamanya masa penyimpanan pada suhu ruang. Oleh karena itu disarankan agar masyarakat dapat mengkonsumsi buah apel yang masih segar dan tidak menyimpan buah apel pada suhu ruang untuk mendapatkan vitamin $\mathrm{C}$ yang cukup.

\section{DAFTAR RUJUKAN}

deMan, J.M., 1997. Kimia Makanan. Bandung: ITB.

Murray R.K., Granner D.K., Mayes P.A., Rodwell V.W. (2003). Harper's Illustrates biochemistry, 26th Ed. New York: McGraw-Hill

Fauziah, R., 2015. Cantik Sehat \& Awet Muda Dengan Buah \& Sayur. Yogyakarta: Notebook

Helmiyesi, Hastuti, R.B., Prihastanti, E., 2008. Pengaruh Lama Penyimpanan Terhadap Kadar Gula dan Vitamin C pada Buah Jeruk Siam ( Citrus nobilis var. microcarpa ). Buletin Anatomi dan Fisiologi. 16(2) : 1-5.

Karinda, M., Fatimawali, Citraningtyas, G., 2013. Perbandingan Hasil 
94 Jurnal Kebidanan Dan Kesehatan Tradisional, Volume 3, No 2, September 2018, hlm 57-106

Penetapan Kadar Vitamin C
Mangga Dodol
Menggunakan
Spektrofotometri UV-Vis dan
Iodimetri. Jurnal Farmasi. 2(1) :
86-89.

Rachmawati, R., Defiani, M.R., Suriani, N.L., 2009. Pengaruh Suhu dan Lama

Penyimpanan terhadap Kandungan Vitamin C pada Cabai Rawit Putih (Capsicum frustescens). Jurnal Biologi. $13(2): 36-40$

Sulistyoningsih, H., 2012. Gizi Untuk Kesehatan Ibu Dan Anak. Yogyakarta:Graha Ilmu.

Safaryani, N., Haryanti, S., Hastuti, E.D., 2007. Pengaruh Suhu dan LamaPenyimpanan terhadap Penurunan Kadar Vitamin C Brokoli (Brassicaoleracea L). Buletin Anatomi dan Fisiologi. 15(2) : 1-8. 